\title{
Assessment of Teachers' and Students' Perceptions of New Education Technologies in Business Undergraduate Programs
}

\author{
Fábio Pimenta de Pádua Júnior ${ }^{1, *}$, João Pereira de Castilho Filho ${ }^{1}$, Pedro José Steiner Neto², Zaki Akel Sobrinho ${ }^{1}$ \\ ${ }^{1}$ Programa de Pós-Graduação em Administração - PPGADM, Universidade Federal do Paraná, Curitiba, Brazil \\ ${ }^{2}$ Programa de Mestrado e Doutorado em Administração - PMDA, Universidade Positivo, Curitiba, Brazil \\ *Corresponding author: pimenta70@gmail.com
}

Received September, 17, 2014; Revised November 20, 2014; Accepted December 04, 2014

\begin{abstract}
This article aims to evaluate the positive and negative aspects of a possible adoption of new technologies and methodologies applicable to the education of administration systems, such as PBL, distance learning, and new evaluation systems, taking into account the impact that these can have on the performance of undergraduate Business students. Twelve in-depth interviews were conducted with students and teachers. The results indicate that the use of PBL is viewed with suspicion and restriction by students, while teachers believe that this methodology is a tool that aids student transformation. Distance learning is also viewed with caution by both parties, because of the stigma still attached to it, although both agree that it plays a key role as a teaching aid. Teaching innovations aim for greater student autonomy and multidisciplinary projects, which enable a broader view not restricted to the discipline. Finally, it was found that assessment systems must be reviewed by teachers and that preference is given for mixed forms that take individual aspects of students into account.
\end{abstract}

Keywords: teaching innovation, problem-based learning, distance learning, assessment systems, information and communications technology

Cite This Article: Fábio Pimenta de Pádua Júnior, João Pereira de Castilho Filho, Pedro José Steiner Neto, and Zaki Akel Sobrinho, “Assessment of Teachers' and Students' Perceptions of New Education Technologies in Business Undergraduate Programs.” Journal of Business and Management Sciences, vol. 2, no. 5 (2014): 94-102. doi: 10.12691/jbms-2-5-1.

\section{Introduction}

The world in which we live undergoes a constant process of change, with numerous technological advances that result in frequent changes to major paradigms. This has affected all fields of knowledge, including education. One of the fields that is benefiting from these advances is the teaching of Applied Social Sciences, in particular Business programs. These programs are characterized as being in great demand and by the fact that the knowledge acquired by students can be immediately employed in companies. This obliges education professionals to remain constantly up to date with any new discoveries in their field and to use innovative teaching techniques.

The shortcomings of the current professional qualification model have been hotly debated. The major problems range from lack of interest and apathy of students in the classroom to a lack of initiative and inadequate professional behavior of graduates. There appears to be a consensus that the conventional educational model (e.g., lessons in the classroom) is no longer adequate when it comes to preparing students for a professional career in the real world [16].
In addition to dominating the technical knowledge of their specific field, be it engineering, Business or medicine, higher education students need to acquire a set of skills and attitudes to complement their learning. Working with three categories (knowledge, skills and attitudes) in the classroom seems to be a major challenge. However, according to Ribeiro and Mizukami (2004) [34], authors such as Zabala (1998) [41] believe that this is viable and cite PBL (Problem-based learning) as a possible approach.

The use of high technology equipment, such as MP3 players, palmtops, cellular phones, laptops and data shows, has gained strength with the joining together of the electronics, computing, entertainment and communications industries. This in turn has spurred the development of new Information and Communications Technologies (ICT) in society and in education [31]. ICT includes a set of tools, back-up and channels for handling access to information, which generate new forms of access, new modes of expression and new models for cultural recreation and participation [8].

New ICTs have been conveniently applied in the field of education to provide better access to information than afforded by previous technologies. Furthermore, many of the computers already installed in Brazilian schools provide a favorable environment for the full use of ICTs [24]. 
Education in Brazil has undergone profound changes triggered mainly by the new information technology and telematics revolution, which affects the pillars of the educational process and society. Thus, with the use of new ICTs in the classroom, it is hoped that students can cease to be mere subjects of the learning process and the teacher can stop giving ready and systematized information to students [26].

With the current educational scenario in Brazil, this study aims to evaluate the upsides and downsides of the possible adoption of new technologies and methodologies applicable to teaching systems in Business, such as PBL and distance learning, as well as new assessment systems, taking into account the impact that these may have on the performance of undergraduate students.

\section{Theoretical and Empirical Review}

\subsection{Innovation in Teaching}

Innovation in education is understood as a protagonist practice of teaching that seeks to equate one or more didactic components and results in a breakaway from habitual practices in the classroom [22].

To understand which innovated learning practices can be applied to teaching in Business programs, the following teaching practices mentioned by Suanno and Suanno (2010) [39] were identified: prior knowledge of students; cooperative learning; metacognition; autonomy, criticality and creativity; thought and emotions learning environments; thoughts and feelings and sensitive listening; mediating questions; and education through a work project.

a. Prior knowledge of students: Suanno and Suanno (2010) [39] and Souza (2008) [38] claim that the learning process should take into consideration the previous knowledge of students, with the teacher working to arouse their interest, as their knowledge is insufficient, and to encourage them to create a space for dialogue and relationships and plan activities that can be enriched by their previous experiences. This will aid, stimulate and encourage the construction and deconstruction of knowledge.

b. Cooperative learning: the learning process is collective and social, and cooperative learning is an innovative way of generating knowledge, with all participants collaborating to produce deeper knowledge. For this purpose, it is necessary to build favorable contexts that encourage everyone to participate (teachers and students) and also value the diverse realities of each participant [38].

c. Learning environments: it is important to create challenging environments that are also welcoming and emotionally healthy [30]. These should facilitate the flow in networks energized by the interactions among all the participants and bring to the surface emotions, feelings, desires, intuition and imagination that will generate information [39].

d. Metacognition: process that seeks to identify and understand ways of thinking that can create a potential for learning, understand its intentionality, encourage dialogue and the need to create fundamental questions for students and value written records of mental activity [9,38]. In order for learning to occur, it is essential that there should be a motive, a project, a concern. This can be either individual or social [39].

e. Autonomy, criticality and creativity: one of the consequences of cooperative learning is autonomy, through which students gain the capacity to organize themselves. The teacher then has the responsibility to develop planned activities to raise student awareness of their responsibilities and goals.

f. Thought, emotion and thoughts and feelings: university professors in general do not value their relationship with theirs students, and this impacts interaction between participants in the knowledge network [38]. Innovation can be found in a concern over making the classroom a pleasant, welcoming place that motivates the participants [39].

g. Sensitive listening: as a consequence of the thought and feeling process, there arises a need to create empathic listening that enables individuals to be in tune with each other, which results in an environment of respect, attention and comprehension of the voice of all individuals [5].

h. Mediating questions: these are significant questions that aid the building of a bridge between theory and practice, helping students to think in a more complex way [30].

i. Educating through a work project: Moraes (2008) [30] proposes that curricula should be reorganized using work projects, a counterpoint to the conventional way of organizing by disciplines, in order to work on problemcentered projects.

\subsection{Teaching Methodologies}

\subsubsection{Problem-based Learning}

Problem-based learning (PBL) is a teaching methodology that originated in the medicine program at McMaster University, Canada, in 1969. The approach is student-centered and the idea is that students will learn for themselves. Real or simulated problems are used in order to initiate, focus and motivate the learning of theories, skills and attitudes. PBL is a constructivist method, i.e., knowledge is constructed rather than merely memorized or accumulated. It is based on the results of educational research indicating that activities conducted by students that are based on real life situations aid learning [16]. The main characteristics of the approach are the thematic organization of problems, interdisciplinary integration between theoretical and practical concepts and emphasis on cognitive development. In this way, the student comes to play a more active role and will have to make a greater effort in terms of thought processes, unlike the culture of traditional learning [11].

PBL can be viewed as innovative because it enables the incorporation and integration of concepts of several activities, such as investigation, identification and solution of problems and group work [17]. Furthermore, it provides a way of facing challenges such as connecting concepts to professional practice, preparing students to develop the practice for which they are being prepared [35].

Some authors $[7,34,40]$ suggest that in this methodology learning should be guided by an open problem that does not have a single correct solution. This should be the focus of the learning process, allowing 
students to integrate concepts and necessary skills to solve it. This is one of the fundamental aspects that make PBL different from other learning and teaching processes [34].

PBL is usually implemented throughout the program. However, there are cases when it is employed as a partial educational strategy, i.e., in single disciplines or parts of disciplines. There is a hybrid format of this methodology, with a central nucleus where problems are solved and other disciplines provide support. There is also a partial format in which one or more disciplines are given using PBL within a traditional curriculum [34]. In this model, problems are used to organize, initiate and motivate the learning of some program content and the rest of the content is given with other methods [16].

Whatever format is adopted, the problem used in this methodology should include some characteristics such as being an open problem that allows for several equally valid solutions, being relevant to the professional practice of students and being a problem that students are likely to come up against in their professional lives [36]. According to Duch (1995) [14], the following process is used in PBL:

a. The students are presented with a problem and in groups organize their ideas and prior knowledge related to it and then proceed to define and solve it;

b. Through discussions, the students prepare learning questions regarding the aspects of the problem that they did not understand. These are recorded by the group and the participants define what they know and what they do not know;

c. The students prioritize the learning questions that are produced and decide which ones will be tackled by the group and which will be handled by individuals. They also discuss which resources will be required and where these can be found;

d. In later meetings, the students explore the learning issues and integrate their new knowledge into the context of the problem. In addition, they continue to define new learning questions as they proceed to solve the problem.

Students come to perceive that learning is a continuous process and that there will always be new questions to be answered. In this sense, the role of the teacher in PBL is to guide, explore and encourage student initiatives, i.e., there is no traditional class and there are no simple or direct solutions [14].

The aim of PBL is to build knowledge through seeking the solution to problems, where skills and attitudes are developed during this process that are more important that the solution itself $[17,34]$.

According to Ribeiro and Mizukami (2004) [34] the educational goals of PBL are:

a. The acquisition of an integrated knowledge base;

b. The acquisition of a knowledge base structured on real problems that are found in the professional field in question;

c. The acquisition of a knowledge base linked to processes for solving these problems and the development of an effective and efficient problem solving process;

d. The development of autonomous learning skills and group work skills.

Although PBL tackles real (or potentially real) problems and involves many social and environmental variables that are relative to a real professional context, the problems used in this methodology should be consistent with the cognitive, motor and affective levels of students. The purpose of this is to challenge students as much as possible without frustrating their capacity to solve problems. As in professional practice, in this methodology students do not have all the relevant information and do not know the necessary actions to arrive at a solution. This obliges them to engage in a reflection process, defining and gathering information and analyzing and redefining the problem, in addition to developing problem-solving skills [16].

The PBL learning and teaching process, like any other, has its upsides and downsides. According to Barrows and Neo (2007) [7], the advantages are:

a. It presents students with problems in contexts that are very close to reality;

b. It offers opportunities to elaborate on the information learned during the problem-solving process;

c. It is an active process;

d. It stimulates decision-making capacity;

e. It develops tolerance of uncertainty (there is no single solution to the problems);

f. It stimulates self-learning naturally;

g. It encourages experience, intuition and motivation.

The disadvantages, according to Barrows and Neo (2007) [7], are:

a. Possible rejection by teachers;

b. It requires good planning to avoid becoming a common teaching method in which students assume a passive posture;

c. There is a possibility that students will retain little of what is learned or use the knowledge inappropriately, which means that instructors have to be better prepared;

d. Cases can be concluded by students before fundamental theory has been learned, which can have a negative impact on the correct development of the knowledge structure.

Other tools used in the learning process are concept maps (CM). Concept maps are graphical tools used for organizing and representing knowledge. CM include concepts, which are typically enclosed in boxes. Relationships between concepts are indicated by a connecting line, and words on the line specify the relationship between the two concepts. Concepts are represented in a hierarchical fashion. CM tend to be read progressing from the top (the most general concepts) downward (less general concepts). CM also have crosslinks, which represent relationships between concepts in different segments or domains [32].

Constructing a concept map is a process that involves identifying key concepts in a text or discussion to serve as nodes and then linking the concepts together. This process also includes an analysis and re-synthesis of information, elaboration of knowledge and linking new information to prior knowledge [1].

CM and PBL have parallel purposes, since both are based on a constructivist view of learning (Johnstone \& Otis, 2006). PBL and CM are useful methods for promoting active and meaningful learning, critical thinking and problem-solving skills. Both tools naturally complement each other in facilitating learning [1].

Students may use the maps for the purpose of planning their work, making their own mental network explicit and preparing materials for later formal assessment. The maps are aids for revision and inter-linking of knowledge [20]. 
Mind mapping is a study technique that works by taking information from several sources and displaying it as key words associated with a study topic. During the process, an image representing the central idea is placed in the center of the mind map. Extending from the key central idea are several major branches with keywords accompanied by an image whenever possible. From each of these main branches, more detailed information can be added. When the mind map is complete, the central image (the most general information) forms the starting point and the branch to the top right-hand (more detailed material) is the first branch examined. This process continues in a clockwise fashion [18].

Mind maps are an effective study technique when applied to written material and have many potential applications to clinical education. Mind mapping can be used as a teaching resource, and it enables notes to be written and reviewed quickly. It also allows information to be easily updated. Mind mapping can be used in a variety of ways, including PBL, small-group teaching, personal revision, and as an examination tool [15].

\subsubsection{Distance Learning}

Distance learning is a form of teaching that does not take place in the presence of an instructor or in a classroom. It takes place at a distance. It is made possible by the use of new ICTs and is one of the most cited resources in discussions of the use of these technologies [13].

According to Demo (2005) [13], studies have shown that for a distance learning program to work in a satisfactory way, five basic components are necessary:

1. Materials and content for the program;

2. Competences of professors in the subject, in teaching and in technology, bearing in mind that they will operate in a virtual medium;

3. The communication system of the program, which can be synchronous (allowing collaborative participation) or asynchronous (tutorials or counseling);

4. Technologies to provide support for the program;

5. Assessment methods, which should be rigorous and transparent.

The author [13] also highlights that distance learning programs can occur in three forms:

1. Programs centered on the class with the web as a supporting bulletin board;

2. Classroom learning and extra activities on the web;

3. Operated totally on the web.

\subsection{Teaching Support Tools}

\subsubsection{Virtual Learning Environment}

There are a number of names for web systems for teaching and learning. The most used terms include Learning Management System (LMS), Course Management System (CMS) and Virtual Learning Environment (VLE). LMSs are also software whose main purpose is to offer an electronic register for accessing and managing the environment in order to offer a set of tasks related to teaching. They organize and provide access for teachers, students and administrators to education-related services. While LMSs were projected for learning environments in the corporate world, VLEs are online systems that specifically support academic teaching in the classroom [10].

Moodle (Modular Object-Oriented Dynamic Learning) is a software for the management of learning and collaborative work. It allows the creation of online programs, pages for disciplines, work groups and learning communities. As it is presented as a philosophy for a constructive, social approach to education, it is in constant development. It is also known as CMS, LMS and VLE [17].

Moodle is an open source system of course management that has become very popular among educators around the world as a tool for creating dynamic websites for students. To function, it only needs to be installed in a web server in one of its own computers or in a host company [29].

The Moodle project aims to make the best tools for managing and promoting learning available to educators, and there are many ways in which it can be used [29]:

a. It has features that allow it to be used on a large scale by hundreds of thousands of students, and it can also be used by a primary school or even an education enthusiast;

b. A number of institutions use it as a platform for totally online programs;

c. The activity modules, such as forums, wikis and databases, can be used to build widely collaborative learning communities for a theme. Furthermore, it can be used as a means of supplying content and assessing the learning of students through tasks or tests.

\subsubsection{Assessment Systems}

Assessment is a complex process and should be understood as a means of measuring learning [2, 3]. No matter what teaching method is adopted, it is not possible to assess the student with only one instrument. When a teacher uses only one resource of evaluation, the result may not be reliable because it is restricted to one single moment in time [33]. The role of a teacher is to prepare methods, strategies and materials with a view to improving the teaching and learning process, resulting in better communication between teachers and students, which will enable a positive increase in student performance [19]. A list of the assessment instruments that can be combined to provide better results in the learning and teaching process is given below.

a. Objective test: provides a considerable sample of the knowledge that has been supplied, eliminates the personal traits of students and is easy to judge. However, it is difficult and time-consuming to prepare and requires a great deal of attention from students. It can be in the form of true or false, multiple choice questions, matching items or gap filling [37];

b. Descriptive test: this is the most used and reliable portrait of the actual situation of a student. It requires intelligent questions that will encourage the student to reflect, affording an opportunity to organize his ideas, opinions, viewpoints and knowledge [28]. However, there is a certain amount of subjectivity in judgment because it is not possible to establish a rigid standard of correction [25]. Salinas (2004) [37] notes the importance of establishing clear criteria that will be used in correction to avoid problems later;

c. Oral test: this enables an assessment of the reflexive capacity of the student and his critical argumentation. On 
the other hand, it supplies only a very limited sample of the knowledge required and it is judged subjectively and immediately and can be affected by the personal attributes of each student. Furthermore, questions should be formulated with the same level of complexity for all students to allow a more fair and coherent assessment [37];

d. Creative test or open book test: open book tests help the student to acquire a deeper understanding of a specific situation by selecting the most appropriate sources, providing an opportunity to perfect the learning and teaching process. However, the teacher needs to be careful and make sure that the test does not consist of simply transcribing consulted material. The student should be instructed as to which types of material can be consulted. It is important that this should not be a pop quiz or an instrument of coercion, but rather something that is complementary to the other forms of assessment that are used [25];

e. Individual or group work: for this, the criteria must be clearly defined and an explanation of research sources should be provided, enabling students to express their understanding of the subject. However, the content and topics should be carefully selected and the student should have prior knowledge of the subject. This instrument allows an assessment of the students' maturity regarding the content in addition to achieving the proposed goals [37]. Group work is more complex because it requires an outline of the content for each member of the group, and this can impact the assessment. Furthermore, it may characterize the work of only part of the group, which means there is a need to have clear rules for assessment [25];

f. Seminar: the main objective is to investigate a problem or theme more deeply and with different viewpoints that enable deeper knowledge and understanding. The selected content is analyzed critically, requiring interaction between the different content to avoid the result being only a monologue from the student. Thus, it is necessary for the teacher to determine a study routine, through which he will explain the goals, list the themes, help the student and recommend a minimum amount of further and complementary reading. The teacher should also discuss the assessment criteria, prepare and schedule for presentation and prepare questions to be used during presentations so that he can assess what the students have learned [37];

g. Classroom participation: in this form of assessment, it is necessary for the teacher to observe carefully throughout the school year. However, such observations are insufficient for a complete assessment. It is necessary to set specific and clear goals that determine what should be observed and for what purpose to ensure the success of the learning and teaching process. Furthermore, it also serves as a diary or log of what happens in the classroom [27];

h. Self-assessment: this is a process in which the students themselves assess their own knowledge, skills and attitudes, and become aware of what they are doing right and wrong, their needs and the best way to improve their critical and reflexive thinking [37].

The use of these instruments with considerable interchanging provides teachers with a wider range of assessment.

\section{Methodology}

The study is qualitative and the objective is to assess the perception of students and professors regarding new technologies in the teaching of Business [4]. It is descriptive, as it enables the specification of properties that are relevant to the categories of analysis, where the level and unit of analysis are constituted by individuals [23]. It is a cross-sectional study with a transversal perspective, as the data were collected at a single point in time [6].

From the theoretical framework, the analysis categories and their extensions were generated:

1) Problem-based learning:

a. The importance of its adoption in Business programs;

b. The impact of its adoption;

c. Its upsides and downsides in teaching.

2) Distance learning:

a. The importance of its use in Business programs;

b. Disciplines that would be more appropriate for its use;

c. The impact of its use;

d. The main advantages and disadvantages of using it;

e. Perception of outside opinion.

3) Teaching innovations:

a. The importance of prior knowledge of students in the learning process;

b. The relevance of cooperative learning in teaching;

c. Student autonomy in the learning process;

d. The importance of reorganizing curricula of disciplines using work project and which would be most suitable for this change.

4) Assessment systems: perception of positive and negative aspects of the use of various types, including:

a. Objective, descriptive and mixed tests;

b. Oral tests;

c. Open book tests;

d. Self-assessment (by the student);

e. Individual and group work;

f. Seminars;

g. Participation in the classroom.

The data were collected during personal in-depth interviews with a semi-structured script, recorded using electronic media. The script was prepared in accordance with the analysis categories of the theoretical framework. The individual in-depth interview is a qualitative technique that explores a subject for a purpose related to learning, by seeking information and perceptions of the interviewee for analysis and structured presentation. Furthermore, the use of a semi-structured interview enables the creation of a structure for comparing responses and the articulation of results, making possible a description and analysis in categories [23].

The recorded interviews were transcribed and analyzed using a content analysis technique in order to identify the elements defined in this study. This technique follows a set of systematic procedures that aim to describe the content of coded messages, whether qualitative or not. The recording process is necessary because it enables a literal and complete register of the interview, making the source more reliable and secure [6].

Twelve in-depth interviews were conducted: six with professors and six with students of the Business program at a Federal University in the south of Brazil. Following the methodological recommendations of Babbie (1990) [4] 
and Creswell (2003) [12], the interviewees were allowed to speak freely in an informal atmosphere so that the results would be as reliable as possible.

\section{Analysis of the Results}

The interviews were divided into four stages: (1) PBL; (2) distance learning; (3) teaching innovations and (4) assessment systems. The collected data were analyzed as follows.

\subsection{PBL}

The professors who were interviewed believe that using real problems helps to assimilate concepts when they are used concretely. As there is an abundance of information in many forms, PBL allows students to become a protagonist using their knowledge.

"In the current reality, with an abundance of information, the student must be a protagonist of his knowledge. The Business student has to learn to be autonomous and manage his resources (cognition, time, etc.) to become effective in the processes he uses. This is learning." (Professor E.)

Professors should be better prepared to use this methodology in the classroom to take advantage of its broad range. Furthermore, a pattern could be created for using it in different disciplines. The great advantages of the method are the autonomy of students to solve problems, increased motivation in the classroom and students being better prepared for professional reality. As a downside, the professors mentioned the possibility of generalized abstraction of content, because the responsibility for learning could be exclusively passed on to the student. This in turn could result in insecurity for students or professors as it is different from the more traditional approaches.

"I think it would be well accepted by students and well handled by the teaching staff. However, I think some students and some professors could find it difficult to use this teaching method, either because they do not agree with it or because they are not prepared to deal with it." (Professor M.)

The professors also mentioned the need to have teachers capable of guiding students in this practical application so that they would be up-to-date in relation to the needs of market development and closeness to organizations.

As for the students who were interviewed, they claimed that PBL should be viewed with caution. Those who had a positive view of the method said that it should be implemented gradually. However, those who saw the content as more technical, involving, for instance, statistics and mathematics, would not use the method.

"This method specifically contributes in two ways: first, to the cognitive development of the individual for solving problems, and secondly because it encourages team work, developing collective solutions rather than only individual ones.” (Student R.)

There was also the opinion that students could benefit more from the use of the method. On the other hand, the interviewees viewed PBL in a negative light because they believe that most undergraduate students do not possess sufficient knowledge to take full advantage of the tool, which would lead to a "considerable move towards practical teaching in detriment of theoretical teaching" (Student R.). They also believe that learning would suffer. There was a consensus among the students that one positive aspect would be the development of rationalization, but with the caveat that some disciplines are not as interesting as others to the students. This shows that the use of PBL is a controversial issue among the students. There now follows an interview extract that summarizes the two viewpoints:

"I believe that for the development of skills and attitudes in order to understand organizational problems and develop solutions autonomously, seeking a theoretical basis and bearing in mind that we are dealing with an applied social science, there could be room for it. But I do not believe that this room should become dominant, as the role of the professor in some more theoretical and fundamental disciplines is essential. However, in some more applied, functionalist and managerial disciplines, the use of this learning method could be adopted or some specific subject could be created just to use it. This could be done in the final semesters, using these simulations, since the theoretical bases of the classroom disciplines for students could be given more focus in subjects where students feel that things are more difficult.” (Student D.)

\subsection{Distance Learning}

In the opinion of the professors who were interviewed, distance learning could be useful for students and help them take better advantage of the program. However, care should be taken regarding quality. It should be restricted to theoretical disciplines and those with a conceptual focus and preferably not those that form the nucleus of the program. This would result in greater student autonomy in their learning. As for the impact on the teaching of Business, there could be some discomfort and resistance, on the part of both professors and students, which would mean that it would have to be structured and adapted to the different realities of both.

"In my opinion, the impact would be considerable, because distance learning is still a much questioned teaching method. It is something relatively new. It has worked out in some cases but not in others. I think a great deal depends on the student too, and how he sees distance learning. Students have to be aware that this is a method like any other. It requires work and has to be taken seriously. It does not mean that it is easier or should be more flexible because it is done at a distance. Flexibility is inherent to the format of the course, which in a practical sense means flexible hours. However, it would have to be a well administered program that requires the student to be dedicated and devote time to his studies. It does not mean that it has to be easier or have fewer activities because it is a distance learning program. On the other hand, the teaching staff also has to be aware of their role and the importance of their 'presence' during disciplines." (Professor L.)

The advantages of distance learning included the fact that it encourages greater student autonomy, helping them to become more involved in their own learning and that it increases the number of disciplines on offer to a wider audience. On the other hand, the disadvantages, according to the professors, lie in the difficulty of assessing how 
dedicated students are to the program. They were also concerned about possible lower quality and learning processes. As for the situation of the market, the professors clearly stated that employers still harbor some doubts and may be prejudiced about the format of distance learning.

"Every change generates discomfort and resistance. That is a fact. However, if distance learning is well structured and well thought out and adapted to the different realities of teaching staff and students, the result could be quite positive. I taught on a distance learning program in Public Business at the Federal University of Paraná and I am a professor at a distance learning institution. I often see that the program has the potential to be good. The problem is how it is organized. It is important to prepare support material, but it makes the content more restricted and we know that the student will only read the material that he has in hand. So, how do we motivate him and broaden his focus? But at the end of the day, distance learning is a great challenge that begins with training good professionals to handle it." (Professor M.)

According to some of the students who were interviewed, there is also a certain amount of prejudice against distance learning, and they see it as an accessory that in some cases is becoming the principal tool. They see it as being useful to the Business program and that its use would be as an auxiliary tool to complement classroom activities. For example, materials could be made available for disciplines that would help students gain more from course content. However, they are unanimous when it comes to replacing traditional classes with distance learning. They reject the idea totally. Some voiced the opinion that some instrumental subjects could eventually be switched to a distance learning format, but the assessment would have to be meticulously analyzed prior to application.

"I believe it is possible to use this method in the Business program, where it would be more suitable for certain subjects that do not require more complex interpretation. Distance learning would be better for teaching and learning instrumental materials and content. The assessment system should be mixed, based on the different forms of assessment.” (Student R.)

\subsection{Teaching innovations}

According to the professors who were interviewed, the prior knowledge and experience of students are important to the learning process. However, the lack of maturity often has a negative impact on this process. This can be explained as being due to the low average age of students. As for collective and social learning, the interviewees suggested that an exchange of experiences and opinions plays a fundamental role as they help the future administrator to learn to work in a team. Regarding the possibility of developing student autonomy, they suggested that this would not be essential to the learning process, although they do believe that professors in general should be better prepared for its implementation. Concerning the use of the curriculum for projects, unlike the conventional mode of disciplines, they suggested that both students and professors should be trained to understand the advantages of using the process. This could be fundamental for the student to develop conceptual skills for the application of his knowledge.

"The entire learning process includes the prior experience of students. A lack of maturity often influences the learning process. I believe that previous knowledge [experience] is important in the learning process. It can even help a student to understand an example that the professor gives in the classroom. However, it is not a factor that makes learning viable because maturity is also a learning process. I believe that previous experience is necessary in instrumental [applied] disciplines like logistics, materials, finances, capital markets and accountancy." (Professor M.)

The students in the study considered their previous experiences to be important. Likewise, they believe that the professors should also be experienced and that this would be essential for good class content, enabling a comparison with the experiences of students, which are often not relevant to the discipline. They believe that student autonomy should stem from the student himself, a point in question being seeking knowledge of subjects outside the classroom in order to enrich the discipline. They believe that multidisciplinary projects are positive and enable better interaction between all the content of every discipline of the program.

\subsection{Assessment Systems}

According to the professors who were interviewed, the use of several forms of assessment is helpful when measuring a student's knowledge accurately, rather than using only one form of assessment. This is because a combination can better represent the knowledge acquired by students. As for open book tests, they consider these important because they make the student interpret a given situation rather than discuss concepts. Self-assessment is considered important for students to reflect on the teaching and learning process and their dedication to each discipline. The professors also believe that individual and group work and seminars are essential for the teaching of Business, seeing that they can result in student commitment to the activities undertaken by the group. On the other hand, care should be taken regarding the size of groups, because large teams allow less interested members to contribute very little and more dedicated students are overloaded. Finally, they understand that student participation in the classroom is fundamental as a form of assessment as it aids their learning if they have to participate, debate and expose their point of view. It can also be used to round up grades.

In the opinion of the students who participated in the study, the use of a variety of forms of assessment is a positive way of measuring their learning accurately. They consider oral testing to be an important form of learning when it comes to the reality of the market. However, how extrovert a student is can have an impact on his assessment, which can result in stress. Concerning open book tests, for these to be more effective, they believe that they should be based on more than one theoretical framework and should be more difficult than other forms of tests. Regarding self-assessment, they believe that this is not an effective way to evaluate knowledge. In the words of Student D, “... students who know think that they do not know and those who do not know need a good 
grade. What else is there to say? Greater awareness is required.” Regarding individual and group work, all the students in the study believe that these are positive. They think that these should be a reflection on the theme and not merely a compilation of several texts. However, they should not be the only form of assessment finally, they believe that assessment of participation in the classroom is a complementary form of measuring learning, but the teacher should "be able to spot the difference between outgoing and shy students." (Student P.)

"When it comes to easy correction, objective tests are the best, but the essence of learning is not just 'learning by heart'. Mixed tests are more interesting. The upside is that mixed tests capture discursive [descriptive] ability and reasoning and learning [objective part]. The downside: I don't know if tests are the best way to assess a student because of the psychological pressures involved. This leads students to learn by heart rather than learn effectively.” (Student M.)

Both students and professors agree that it is necessary to use more than only one form of assessment, such as open book tests, individual and group work, seminars and student participation in the classroom. Thus, mixed methods provide a broader view of the knowledge acquired by students in Business undergraduate programs.

A summary of professors' and students' opinions is shown in Table 1.

Table 1. Summary of Results

\begin{tabular}{|c|c|c|}
\hline $\begin{array}{c}\text { Analysis } \\
\text { categories }\end{array}$ & Professors’ opinions & Students' opinions \\
\hline PBL & $\begin{array}{c}\text { Pro: assimilation of concepts; autonomy of students; } \\
\text { increased motivation } \\
\text { Con: generalized abstraction of content; insecurity } \\
\end{array}$ & $\begin{array}{c}\text { Pro: cognitive development; team work; collective solutions } \\
\text { Con: lack of sufficient knowledge to use the tool; impairment of } \\
\text { theoretical teaching }\end{array}$ \\
\hline Distance learning & $\begin{array}{l}\text { Pro: flexibility; greater student autonomy; wider audience } \\
\text { Con: restricted to some disciplines; it may generate } \\
\text { discomfort and resistance }\end{array}$ & $\begin{array}{c}\text { Pro: auxiliary tool to complement classroom activities } \\
\text { Con: prejudice against this method; cannot replace traditional } \\
\text { classes }\end{array}$ \\
\hline $\begin{array}{c}\text { Teaching } \\
\text { innovations }\end{array}$ & $\begin{array}{c}\text { Prior knowledge and exchange of experiences are an aid to } \\
\text { learning }\end{array}$ & $\begin{array}{c}\text { Previous experiences are important; multidisciplinary projects are } \\
\text { positive }\end{array}$ \\
\hline $\begin{array}{c}\text { Assessment } \\
\text { systems }\end{array}$ & Mixed forms of assessment are better & $\begin{array}{l}\text { Mixed forms of assessment are better; lack of maturity for self- } \\
\text { assessment }\end{array}$ \\
\hline
\end{tabular}

\section{Conclusions}

Studies about innovations in education have rapidly intensified, especially because of the various possibilities offered by distance learning. This method is considered a solution to the problems of countries that are still struggling against the lack of universal levels and access to basic education, as is the case of Brazil [21]. Authors such as Demo (2005) [13] point out that ICTs open up new perspectives, such as the speed of individual learning and the breaking of barriers such as distance and time. To this author, there is no escaping technology in education. Its introduction and use are inevitable and this will have to be accepted one way or another. It is believed that students today are not very much motivated by the classroom, but that they are motivated by the new ICTs and the endless use of the computer.

Concerning the implementation of PBL, there were differences in the opinions of the professors and students who were interviewed. The students were divided into those who thought that PBL has a positive or a negative impact, especially because they believe that students are too immature to use the tool and that its use would lead to a shift towards practical teaching in detriment of theory. On the other hand, the professors believed that PBL is an instrument that helps to transform the student, making him a protagonist rather than a mere spectator in the building of his knowledge.

Concerning distance learning, the students take a negative view of it, considering it only as an auxiliary teaching instrument. The professors, however, view it as beneficial, although they believe that change brings discomfort and resistance on the part of both professors and students. Although they believe that distance learning can lead to student autonomy, they agree that it should not be used as a single form of teaching, substituting classroom teaching. They also highlight that the market still views distance learning graduates in a negative light.

On the subject of teaching innovations, the students and professors agreed that students' prior experiences are an aid to learning. Furthermore, student autonomy to seek the means to complement knowledge acquired in the classroom and multidisciplinary projects enable a view of the whole, and learning is not restricted to the content of each discipline. From the students' point of view, multidisciplinary projects, involving more than the content of a single course would enrich learning, provided there is a wider objective requiring knowledge and skills not covered in a single course.

Both students and professors believe that combined assessment methods are better than a single form. However, they disagree on self-assessment. The professors believe that it is important for students to reflect on their own learning, while the students view this form of assessment with mistrust as they believe that most students are not mature enough for it.

Finally, the students and professors agreed on the use of different forms of assessment and the use of distance learning as a way of complementing learning. However, they differed regarding the ability of the student to work actively and maturely in learning, as the students believe that most are still too immature to use the various instruments. On the other hand, the professors believe that the students are sufficiently mature.

In order to develop and sustain any change in the educational system, the professionals involved in education should seek to outline, explore and implement new educational technologies, going beyond the traditional teacher-student paradigm.

This study contributes to the field with its evaluation of the perceptions of students and professors regarding the eventual adoption of new teaching technologies. Their views have some critical elements that can help (or even enable) the adoption of certain innovations. As the 
qualitative approach does not allow for generalization, a quantitative study should be conducted to gauge more objectively the points on which the students and professors agree and disagree. Future studies could also assess how these new technologies could improve undergraduate performance in Business and pave the way for the successful adoption of information and communication technologies.

\section{Acknowledgement}

Financial aid received from the CAPES/REUNI program.

\section{References}

[1] Addae, J. I., Wilson, J. I. \& Carrington, C. (2012). Students' perception of a modified form of PBL using concept mapping. Medical Theacher 34, e756-e762.

[2] Almeida, A. M. F. P. M. (1992). Um estudo sobre a avaliação da aprendizagem em um curso superior de ciências agronômicas. Tese de Doutorado não publicada, Faculdade de Educação, Unicamp, Campinas, SP, Brasil.

[3] Almeida, A. M. F. P. M. (1997). Avaliação da aprendizagem e seus desdobramentos. Avaliação, 2 (2), 37-50.

[4] Babbie, E. (1990). Survey Research Methods. Belmont: Wadsworth Publishing Company.

[5] Barbier, R. (2002). Escuta sensível na formação de profissionais de Saúde. Anais da Conferência na Escola Superior de Ciências da Saúde-FEPECS, SES-GDF, Brasília, DF, Brasil. Retrieved Aug 8, 2011, from http://www.barbierrd.nom.fr/ESCUTASENSIVEL.PDF.

[6] Bardin, L. (2009). Análise de Conteúdo. Lisboa: Edições 70.

[7] Barrows, H. S., \& Neo, L. W. (2007). Principles and Practice of $A P B L$. Singapore: Pearson Prentice Hall.

[8] Belloni, M. L. (2003). Educação a distância. Campinas: Autores Associados.

[9] Brunner, J. (1998). Cultura da educação. Lisboa: Edições 70.

[10] Carvalho Neto, S., \& Takaoka, H. (2009). Ambientes Virtuais de Aprendizagem de Código Livre como Apoio ao Ensino Presencial na Área de Ciências Sociais Aplicadas: Um Estudo de Caso em uma Instituição de Ensino Superior. Anais do Encontro Nacional da Associação Nacional de Pós-Graduação e Pesquisa em Administração, São Paulo, SP, Brasil, 33.

[11] Costa, V. C. I. (2001). Aprendizagem baseada em problemas (PBL). Revista Távola Online, 5.

[12] Creswell, J. W. (2003). Research design: qualitative, quantitative and mixed methods approaches. Thousand Oaks: Sage.

[13] Demo, P. (2005). Éticas Multiculturais-Sobre convivência humana possível. Petrópolis: Vozes.

[14] Duch, B. (1995). What is problem-based learning? Center for Teaching Effectiviness. [E-book] Retrieved Aug. 3, 2011, from http://www.udel.edu/pbl/cte/jan95-what.htm.

[15] Edwards, S., \& Cooper, N. (2010). Mind mapping as a teaching resource. The Clinical Teacher, 7, 236-239.

[16] Escrivão Filho, E., \& Ribeiro, L. R. C. (2009). Aprendendo com PBL-Aprendizagem Baseada em Problemas: Relato de uma experiência em cursos de engenharia da EESC-USP. Revista Minerva, 6 (1), 23-30.

[17] Farina, R. M. (2008). Contribuições do ambiente virtual de aprendizagem para o desenvolvimento de competências do engenheiro de produção utilizando o $P B L$. Dissertação de Mestrado, Universidade de São Paulo, São Paulo, SP, Brasil.
[18] Farrand P., Hussain, F., \& Hennessy, E. (2002). The Efficacy of Mind Mapping as a Study Technique. Medical Education, 36, 426-431.

[19] Gronlund, N. E. (1979). O sistema de notas na avaliação do ensino. São Paulo: Pioneira.

[20] Johnstone, A. H., \& Otis, K. H. (2006). Concept mapping in problem based learning: a cautionary tale. Chemistry Education Research and Practice, 7 (2), 84-95.

[21] Korelo, J. C., Prado, P. H. M, \& Silva, D. M. L. (2010). Escolha adoção de tecnologias de informação e comunicação na educação. Revista de Administração e Inovação, 7 (2), 80-103.

[22] Lucarelli, E. (2009). Teoria y práctica en La universidad-La innovación en las aulas. Buenos Aires: Mino y Dávila.

[23] Malhotra, N. K. (1999). Marketing Research: an applied orientation. London: Prentice-Hall International.

[24] Marinho, S. P. P. (2006). Novas tecnologias e velhos currículos; já é hora de sincronizar. Revista E-Curriculum, 2 (3), 35-38.

[25] Masetto, M. (2001). Atividades pedagógicas no cotidiano da sala de aula universitária: reflexões e sugestões práticas. In: Castanho, $\mathrm{S}$, \& Castanho, M. E. (Orgs). Temas e textos em metodologia do ensino superior. ( $2^{\text {nd }}$ ed). Campinas: Papirus.

[26] Masetto, M. (2004). Innovation in higher education. InterfaceComunicação, Saúde, Educação, 8 (14).

[27] Melchior, M. C. (1994). Avaliação Pedagógica: função $e$ necessidade. Porto Alegre: Mercado Aberto.

[28] Mendez, J. M. A. (2002). Avaliar para conhecer, examinar para excluir. Porto Alegre: Artmed.

[29] Moodle. (2011). Sobre o MOODLE. Retrieved Aug. 5, 2011 from: http://moodle.org/about/.

[30] Moraes, M. C. (2008). Pensamento eco-sistêmico: educação, aprendizagem e cidadania no século XXI $\left(2^{\text {nd }}\right.$ ed). Petrópolis: Vozes.

[31] Nakashima, R. H. R., \& Amaral, S. F. (2006). A Linguagem Audiovisual da Lousa Digital Interativa no Contexto Educacional. ETD-Educação Temática Digital, Campinas, 8 (1), 33-50.

[32] Novak J. D., \& Cañas, A. J. (2008). The theory underlying concept maps and how to construct and use them. Technical Report IHMC Cmap Tools 2006-01 Rev 01-2008, Florida Institute for Human and Machine Cognition, available at: http://cmap.ihmc.us/ Publications/ResearchPapers/TheoryUnderlyingConceptMaps.pdf.

[33] Oliveira, K. L., \& Santos, A. A. A. (2005). Compreensão em leitura e avaliação da aprendizagem em universitários. Psicol. Reflex. Crit., 18 (1), 118-124.

[34] Ribeiro, L. R. C., \& Mizukami, M. G. N. (2004). Uma Implementação da Aprendizagem Baseada em Problemas (PBL) na Pós-Graduação em Engenharia sob a Ótica dos Alunos. Semina: Ciências Sociais e Humanas, Londrina, 25 (1), 89-102.

[35] Ribeiro, L. R. C. (2005). A Aprendizagem baseada em problemas (PBL): uma implementação na educação de engenharia na voz dos atores. Tese de Doutorado, UFSCAR, São Carlos, SP, Brasil.

[36] Ribeiro, L. R. C. (2008). Aprendizagem Baseada em ProblemasPBL: uma experiência no ensino superior. São Carlos: EDUFSCar

[37] Salinas, D. (2004). Prova amanhã: entre a teoria e a realidade. Porto Alegre: Artmed.

[38] Souza, C. R. (2008). Universidade processo de ensino aprendizagem e inovação. Anais do ENANPED Centro-Oeste, ANPED, Brasília, DF, Brasil, 9.

[39] Suanno, M. V. R., \& Suanno, J. H. (2010). Educação superior e práticas pedagógicas inovadoras: contribuições da complexidade e transdisciplinaridade. Proceedings of the Congresso Internacional sobre Transdisciplinaridad, Complejidad y ecoformación, San José, Costa Rica, 4.

[40] Woods, D. R. (2014). Problem-Based Learning (PBL). MacMaster University, Department of Chemical Engineering Web Site. Retrieved Oct. 16, 2014, from: http://chemeng.mcmaster.ca/ problem-based-learning

[41] Zabala, A. (1998). A prática educativa: como ensinar. Porto Alegre: Artmed. 